\title{
Analisis Pengaruh Kualitas Produk dan Promosi terhadap Keputusan Pembelian Produk Kartu Seluler Indosat
}

\author{
Agus Fitri Yanto \\ Jurusan Administrasi Bisnis, Fakultas Ekonomi, Politeknik Sawunggalih Aji \\ Email: agusfy@polsa.ac.id
}

\begin{abstract}
This research was conducted to determine product quality and promotion effect on the purchasing decision to Indosat cellular card products. The F test results $=10.457(0,000$ $<0.05)$ indicate that product quality and promotion variables influence student purchasing decisions on Indosat cellular card. At the significance level 5\%, product quality has a significant positive impact on Indosat product purchasing decisions. The t-test shows the value of Sig. constant 0.001 , product quality 0.001 (<0.05), then product quality variables have a significant effect on purchasing decisions. While the value of Sig. sales of 0.960 indicate that promotion does not have a significant effect on the decision to purchase Indosat products. In this case the product quality, promotion and purchasing decisions are positively less strong (the correlation is 0.4999 and $0.326<0.5$. However, because of the large positive correlation (+) it shows that the higher the product quality and Indosat promotion, the decision to buying Indosat products remains a growing trend, but the determination test shows $R 2$ of 2,249, or 24.9\%, which means there are still many aspects that influence the decision to buy or use Indosat cellular cards outside the quality and promotion aspects of the product.
\end{abstract}

Keywords: Quality Products, Promotion, Purchase Decision

\begin{abstract}
Abstrak
Penelitian ini dilakukan untuk mengetahui pengaruh kualitas produk dan promosi pada keputusan pembelian kartu seluler Indosat. Hasil uji $F=10,457 \quad(0,000<0,05)$ menunjukkan bahwa kualitas produk dan promosi secara bersama-sama mempengaruhi keputusan pembelian kartu seluler Indosat mahasiswa. Pada tingkat signifikansi $=5 \%$, kualitas produk memiliki dampak positif yang signifikan terhadap keputusan pembelian produk Indosat. Berdasarkan hasil uji-t, nilai Sig. konstan $=0,001$, kualitas produk $=$ 0,001 (<0,05), maka variabel kualitas produk berpengaruh signifikan terhadap keputusan pembelian. Sedangkan nilai Sig. penjualan 0,960 menunjukkan bahwa variabel promosi tidak berpengaruh cukup signifikan terhadap keputusan pembelian produk Indosat. Dalam hal ini kualitas produk, promosi dan keputusan pembelian berkorelasi positif yang kurang kuat (korelasi besarnya 0,4999 dan 0,326 <0,5. Namun, karena besarnya korelasi positif (+) itu menunjukkan bahwa semakin tinggi kualitas produk dan promosi Indosat, keputusan untuk membeli produk Indosat tetap menjadi trend yang sedang berkembang. Namun uji determinasi menunjukkan 22 sebesar 2.249, atau 24,9\%, yang berarti masih banyak aspek yang mempengaruhi keputusan pembelian atau menggunakan kartu seluler Indosat di luar aspek kualitas dan promosi produk.
\end{abstract}

Kata kunci: Kualitas Produk, Promosi, Keputusan Pembelian

\section{PENDAHULUAN}

Sejak tahun 2000-an teknologi informasi dan komunikasi di Indonesia berkembang cukup pesat. Batasan ruang dan waktu bagi setiap orang menjadi semakin sempit dengan berbagai perangkat telekomunikasi. Kalau pada awal tahun 2000-an, untuk melakukan komunikasi jarak jauh orang harus mencari warung telekomunikasi (wartel), maka saat ini orang dengan mudah dapat melakukan setiap saat hanya dengan telepon genggam. Keberadaan perangkat teknologi yang satu ini hampir dipastikan setiap orang memilikinya. Sebagai contoh setidaknya dalam satu rumah ada satu perangkat telepon genggam. Hal ini tentunya tidak mengherankan karena harganya yang semakin terjangkau. Kalau dulu orang harus membeli merek-merek branded seperti Nokia, Siemens, Erickson, Sony, Samsung dan sejenisnya, maka saat ini sudah banyak tersedia berbagai produk merek lokal asal dari China. Produk-produk dengan harga terjangkau itu antara lain 
mengusung merek Cross, G-Star, ZTE, IMO, Nexian, Kfone, Isis, Asiafone, CSL Blueberry, SPC dan lainnya.

Telepon genggam pun saat ini tidak haya sekedar dapat digunakan untuk komunikasi melalui panggilan langsung dan SMS saja. Berbagai fitur telah hadir dan memberikan kemudahan bagi para penggunanya. Mulai dari mengirim gambar via bluetooth, mendengarkan lagu, memotret, merekam video, dual simcard hingga urusan berselancar di dunia maya melalui internet. Tapi kehadiran telepon genggam bukanlah apa-apa tanpa adanya produk pendukung berupa kartu seluler. Berbagai merek kartu seluler yang dikeluarkan oleh para vendorpun semakin beragam mulai dari yang pra bayar hingga pasca bayar maupun GSM hingga CDMA. Sebagai contoh yaitu Simpati, Kartu As, Halo, Mentari, M3, Matrix, XL, 3, Axis, Esia, Smartfren dan Flexi. Kartu seluler inipun semakin didukung dengan berbagai teknologi dan fasilitas seiring semakin tingginya teknologi telepon genggam.

Berbagai program juga digulirkan oleh para vendor karena persaingan yang semakin ketat. Salah satunya yaitu harga kartu perdana selular yang seakan mirip orang membeli jajanan karena hanya dalam kisaran Rp1.000,- hingga Rp5.000,-. Akhirnya fenomena komunikasi menggunakan perangkat seluler ini di Indonesia semakin merambah dari perkotaan hingga pelosok desa dan dari kalangan dewasa hingga anak-anak. Dari urusan antar personal, keluarga hingga pekerjaan maupun bisnis sulit dipisahkan dari telepon genggam dan kartu seluler. Status perangkat selulerpun seakan naik peringkat menjadi 'kebutuhan primer'.

Adapun salah satu vendor penyedia layanan seluler ini adalah Indosat. Indosat sebagai salah satu perusahaan telekomunikasi dengan pemerintah sebagai pemegang saham utama, hingga saat ini menyediakan layanan komunikasi seluler pra bayar dengan merek Mentari dan M3. Sedangkan untuk pasca bayar, Indosat menyediakan Matrix. Dengan berbagai layanannya, hingga triwulan I 2012 Indosat mampu memiliki pelanggan mencapai 52,1 juta nomor. Kondisi ini naik 14\% dibanding periode yang sama pada 2011 (www.republika.co.id, 14 Mei 2012). Sedangkan pada tahun 2013, berdasarkan laporan keuangan Indosat diketahui bahwa jumlah pelanggan hingga kuartal kedua 2013 adalah sebanyak 56,5 juta pelanggan, meningkat dari kuartal 12013 sebesar 55,9 juta atau dari kuartal kedua 2012 sebanyak 50,9 juta pelanggan (www.merdeka.com, 2 Agustus 2013).

Sebagaimana diulas di republika.co.id (14 mei 2012), penambahan jumlah pelanggan seluler Indosat didorong oleh peningkatan kepercayaan masyarakat terhadap produk Indosat, termasuk pendapatan dari sewa menara. Periode Maret 2011-Maret 2012, penambahan pelanggan baru sebanyak 6,4 juta nomor. Dengan pencapaian tersebut, Indosat menguasai pangsa pasar seluler di tanah air sebesar 21,7 persen atau peringkat kedua terbesar setelah pelanggan Telkomsel. Tidak mau tertinggal oleh operator lain, Indosat juga merilis program untuk meningkatkan jumlah pelanggan baru dan meretensi pelanggan lama. Salah satunya yaitu bagi para pelanggan BlackBerry Indosat yang sudah mencapai 1,8 juta orang pada medio 2012 lalu. Program baru itu adalah Super Bonus Paket Berlangganan BlackBerry, yang diantaranya adalah program Bundling BlackBerry Facebook. Program ini untuk merayu pengguna feature phone agar mau beralih ke smartphone BlackBerry (www.detik.com, 24 Oktober 2012). Indosat terus meningkatkan jumlah pelanggan data dan pelanggan BlackBerry. Dari 55,5 juta pelanggan Indosat pada kuartal ketiga 2012 ini 20\% di antaranya adalah pelanggan data.

Perkembangan pesat itu kemudian ditindaklanjuti oleh Indosat dengan melakukan modernisasi jaringan pada kuartal I dan II 2013 untuk meningkatkan kapasitas menampung pelanggan Indosat yang bertambah, disamping merapatkan jangkauan jaringan layanan seluler $3 \mathrm{G}$ (www.investor.co.id, 14/12/2012). Trafik data juga meningkat 67,5 persen dari semester 12012 menjadi 5.904 TB atau meningkat 12,3 persen dari kuartal 1/2013 sebesar 5.257 TB. Peningkatan trafik layanan seluler tersebut didukung oleh infrastruktur BTS sebanyak 22.449 unit hingga semester 1/2013 yang meliputi 17.668 unit BTS 2G dan 4.781 unit BTS 3G (www.merdeka.com, 2 Agustus 2013).

Berdasarkan latar belakang di atas, penelitian ini mengambil rumusan masalah yaitu bagaimana pengaruh kualitas produk dan promosi terhadap keputusan pembelian produk kartu seluler Indosat. Penelitian analisis pengaruh kualitas produk dan promosi terhadap keputusan pembelian produk kartu seluler Indosat, dilakukan dengan responden yaitu mahasiswa Politeknik 
Sawunggalih Aji Purworejo yang menggunakan produk kartu seluler dari PT Indosat tbk. Adapun tujuan dari penelitian ini adalah untuk mengetahui pengaruh kualitas produk dan promosi terhadap keputusan pembelian produk kartu seluler Indosat.

\section{METODE PENELITIAN}

Penelitian ini menggunakan variabel sebagai berikut :

1. Variabel independen $(\mathrm{X})$ terdiri dari :

a. $X 1=$ Kualitas produk, digunakan untuk mengukur tingkat kualitas produk Indosat dalam persepsi pelanggan, dengan indikator yaitu :

1) Kesesuaian produk Indosat dengan kebutuhan pelanggan.

2) Keunggulan produk Indosat jika dibandingkan dengan pesaing.

3) Kemampuan produk Indosat memberikan kepuasan bagi pelanggan.

4) Kuantitas pengguna produk Indosat.

5) Kesesuaian produk Indosat dengan selera pelanggan.

6) Jaminan kualitas produk dan layanan dari Indosat.

b. $X 2$ = Promosi, digunakan untuk mengukur promosi dalam persepsi pelanggan, dengan indikator yaitu :

1) Perkenalan produk Indosat melalui iklan.

2) Penyampaian pesan iklan terhadap produk Indosat.

3) Dampak keunggulan produk yang dipromosikan.

4) Iklan yang diterapkan dapat membangun pelanggan yang loyal.

5) Kejelasan pesan tentang inovasi produk dalam iklan Indosat.

2. Variabel Dependen (Y) adalah Keputusan Pembelian

Keputusan pembelian merupakan variable dependen yang keberadannya dipengaruhi oleh berbagai factor, dengan indikator yaitu :

a. Kesetiaan menggunakan produk Indosat.

b. Tingkat pembelian ulang pada produk Indosat.

c. Ketetapan memakai produk Indosat walaupun ada informasi negatif.

d. Kepindahan ke produk lain selain produk Indosat.

e. Loyalitas karena citra (image) Indosat pada pelanggan yang positif.

f. Loyalitas pelanggan karena kualitas produk yang dijual Indosat.

Populasi dalam penelitian ini adalah mahasiswa pengguna kartu selular Indosat di Politeknik Sawunggalih Aji. Untuk memudahkan maka peneliti akan menyebarkan kuesioner dengan jumlah sampel sebanyak 66 orang. Teknik pengambilan sampel menggunakan metode Non Probability Sampling yang tidak memberi peluang atau kesempatan yang sama bagi setiap unsur populasi untuk dipilih menjadi sampel. Teknik samplingnya adalah sampling aksidental dengan penentuan sampel berdasarkan kebetulan, dimana siapa saja yang secara kebetulan bertemu dengan peneliti dapat digunakan sebaga sampel, bila dipandang orang itu cocok sebagai sumber data.

Data dalam penelitian ini yaitu terdiri dari data primer dan data sekunder. Data primer diperoleh secara langsung dengan menyebarkan kuesioner kepada sejumlah mahasiswa responden secara langsung untuk memperoleh tanggapan mengenai variabel kualitas produk, promosi dan keputusan pembelian pada mahasiswa pengguna jasa kartu seluler dari PT Indosat tbk di Politeknik Sawunggalih Aji Kutoarjo Kabupaten Purworejo.

Teknik pengumpulan data yang digunakan untuk penelitian lapangan yaitu interview (wawancara), kuesioner (angket) dan observasi (pengamatan). Kuesioner diberikan kepada para mahasiswa pengguna kartu seluler PT Indosat tbk di Politeknik Sawunggalih Aji. Pengumpulan data melalui observasi dilakukan dengan pengamatan langsung untuk mendukung kebenaran dan mengurangi kekeliruan pengguna jasa dalam menjawab pertanyaan yang mungkin timbul. Studi Pustaka untuk menunjang keabsahan penelitian maka pengumpulan data dilakukan pula dengan studi pustaka melalui buku-buku materi tentang manajemen pemasaran dan pemasaran jasa, literatur, dan bacaan terkait.

Penelitian ini menggunakan beberapa alat analisis yang dimungkinkan dapat dioperasionalisasikan berkaitan dengan obyek penelitian, yaitu : 
1. Analisis Deskriptif, Mengulas rincian deskriptif mengenai pengguna kartu selular Indosat dengan memberikan gambaran secara deskriptif antara lain mengenai jenis kelamin, jenis produk, usia, lama pemakaian, orientasi penggunaan kartu dan jumlah konsumsi pulsa.

2. Uji Validitas, butir kuesioner valid apabila nilai $\mathrm{r}$ hasil yang diperoleh dari perhitungan (product moment) lebih besar dari pada nilai $r$ tabel ( $r$ hasil $>r$ tabel ) atau jika nilai koefisien korelasi lebih dari 0,244 untuk taraf signifikansi 5\% (Sugiyono, 2007:317).

3. Uji Reliabilitas, dilakukan untuk mengetahui sejauh mana suatu alat ukur dapat dipercaya dan relatif konsisten bila dilakukan pengukuran dua kali atau lebih terhadap gejala yang sama dengan alat ukur yang sama.

4. Koefisien Korelasi, untuk mengetahui kuat lemahnya hubungan antar variabel independen dan hubungan variabel independen dengan variabel dependen, dinyatakan dengan fungsi linear dan diukur dengan koefisien korelasi.

5. Regresi (Uji-t), Hipotesis menyatakan bahwa variabel bebas mempunyai pengaruh yang signifikan terhadap bariabel terikat. Pengujian kebenaran ini menggunakan pengujian koefisien regresi. Persamaannya sebagai berikut : $\mathrm{Y}=\beta_{\mathrm{O}}+\beta_{1} \mathrm{X}_{1}+\beta_{2} \mathrm{X}_{2}+\beta_{3} \mathrm{X}_{3}+\varepsilon$

6. Pengujian Hipotesis

A. Uji Parsial (uji-t)

$\mathrm{H}_{\mathrm{o}}: \beta_{1} \neq 0$ : tidak terdapat pengaruh signifikan kualitas produk dan promosi terhadap keputusan pembelian.

$\mathrm{H}_{\mathrm{a}}: \beta_{1}=0$ : terdapat pengaruh signifikan kualitas produk dan promosi terhadap keputusan pembelian.

Apabila nilai sig $<0,05$ maka $\mathrm{H}_{\mathrm{o}}$ ditolak, yang berarti ada pengaruh signifikan variabel independen terhadap variabel dependen. Jika nilai sig $>0,05$ berarti ada pengaruh tidak signifikan variabel independen terhadap variabel dependen.

B. Uji Simultan (Uji F), jika nilai sig > 0,05 berarti terdapat pengaruh tidak signifikan variabel independen terhadap variabel dependen.

\section{HASIL DAN PEMBAHASAN}

Beberapa penelitian lain telah menunjukkan berbagai faktor yang mempengaruhi keputusan pembelian oleh konsumen terhadap suatu produk. Salah satunya yaitu Tuti Budiarti (2012) yang meneliti pengaruh citra merek (brand image) terhadap pengambilan keputusan pembelian motor Kawasaki pada PT. Diana Indonesia di Makassar. Penelitian Tuti Budiarti (2012:38) menunjukkan bahwa variabel citra merek yang terdiri dari atribut, kepribadian, dan manfaat secara bersama-sama memiliki pengaruh yang positif terhadap variabel keputusan pembelian motor Kawasaki pada PT. Diana Indonesia di Makassar.

Adapun berdasarkan uji t, hasil yang diperoleh yaitu semua variabel citra merek (brand image) berpengaruh positif dan signifikan terhadap keputusan pembelian motor Kawasaki pada PT. Diana Indonesia di Makassar. Dari penelitian ini menunjukkan bahwa sebesar 59,2\% Keputusan Pembelian konsumen terhadap pembelian motor Kawasaki dipengaruhi oleh variasi dari ketiga variabel independen, yaitu atribut, kepribadian, manfaat, Sedangkan sisanya sebesar 40,8\% dipengaruhi oleh variabel-variabel lainnya yang tidak diteliti.

Sedangkan Qarina (2012) meneliti faktor-faktor yang mempengaruhi permintaan kredit sepeda motor di kota Makassar. Tujuan dari penelitian ini adalah untuk mengetahui dan menganalisis besarnya pengaruh pendapatan, biaya angsuran, jangka waktu pengembalian kredit, dan harga tunai sepeda motor terhadap permintaan kredit sepeda motor di Kota Makassar tahun 2012. Hasil penelitiannya menunjukkan bahwa pendapatan, biaya angsuran, jangka waktu pengembalian kredit, dan harga tunai sepeda motor berpengaruh positif terhadap permintaan kredit sepeda motor di Kota Makassar tahun 2012. Sebagai tambahan, biaya angsuran dan jangka waktu pengembalian kredit berpengaruh positif dan signifikan terhadap permintaan kredit sepeda motor di Kota Makassar tahun 2012. Sedangkan pendapatan, dan harga tunai sepeda motor berpengaruh positif dan tidak terlalu signifikan terhadap permintaan kredit sepeda motor di Kota Makasar 2012.

Keputusan pembelian menurut Fausi Arman (2010) yang meneliti faktor-faktor yang memengaruhi keputusan pembelian laptop merek Acer pada Mahasiswa Fakultas Kesehatan 
Masyarakat USU Medan juga dipengaruhi oleh kualitas, merek dan promosi. Ketiganya berpengaruh signifikan terhadap keputusan pembelian. Dharmayansyah Djumaing (2012) juga pernah meneliti mengenai faktor-faktor yang memengaruhi konsumen terhadap pembelian semen pada PT. Semen Tonasa di Kabupaten Pangkep. Dari hasil penelitiannya dapat disimpulkan bahwa faktor kualitas produk, citra merek, harga dan promosi mempunyai pengaruh yang signifikan terhadap keputusan konsumen dalam pembelian semen. Dari hasil pengujian koefisien regresi maka diperoleh hasil bahwa faktor yang paling dominan berpengaruh terhadap keputusan konsumen adalah kualitas produk.

Pada penelitian ini, Uji validitas pada masing-masing variabel kualitas produk (X1), promosi (X2) dan keputusan pembelian (Y), korelasi item pertanyaan terhadap variabel mempunyai nilai korelasi > 0,3 sehingga item pertanyaan tersebut dinyatakan valid dalam menjelaskan variabelnya. Sedangkan dari hasil uji reliabilitas dapat diketahui bahwa pernyataan mengenai kualitas produk $(X 1)$, promosi $(X 2)$ dan keputusan pembelian $(Y)$ menurut kriteria dikatakan reliabel karena koefisien Cronbach Alpha > nilai kritis 0,60 sehingga dapat digunakan sebagai instrumen penelitian.

\section{Tabel 1. Uji Determinasi}

Model Summary

\begin{tabular}{|l|l|l|l|l|}
\hline Model & $\mathrm{R}$ & $\mathrm{R}$ Square & $\begin{array}{l}\text { Adjusted } \mathrm{R} \\
\text { Square }\end{array}$ & $\begin{array}{l}\text { Std. Error of } \\
\text { the Estimate }\end{array}$ \\
\hline 1 & $.499^{\mathrm{a}}$ & .249 & .225 & 3.29374 \\
\hline
\end{tabular}

a. Predictors: (Constant), Promosi, KualitasProduk

(Sumber : Data primer diolah)

Pada uji determinasi diketahui besarnya $\varepsilon=(1-\mathrm{R} 2)=(1-0,249)=0,751$ atau $75,1 \%$. Dalam hal ini dari uji $\mathrm{R}^{2}$ didapatkan hasil sebesar 0.249 atau $24,9 \%$ yang berarti variabilitas variabel dependen yang dapat dijelaskan oleh variabilitas variabel independen hanya sebesar $24,9 \%$. Sedangkan sisanya $(75,1 \%)$ dijelaskan atau terwakili oleh variabel lainnya yang tidak dimasukkan dalam model regresi dan tidak diteliti dalam penelitian ini. Sedangkan uji F menunjukkan nilai $\mathrm{F}=$ 10,457 dengan nilai signifikansi $0,000<0,05$. Maka model regresi ini bisa dipakai untuk melihat tingkat keputusan pembelian kartu seluler seseorang. Berarti secara bersama-sama variabel bebas kualitas produk dan promosi mempengaruhi keputusan pembelian mahasiswa Politeknik Sawunggalih Aji pada produk kartu seluler Indosat.

\section{Tabel 2. Uji F} ANOVA $^{\mathrm{a}}$

\begin{tabular}{|l|ll|l|l|l|l|}
\hline Model & $\begin{array}{l}\text { Sum } \\
\text { Squares }\end{array}$ & df & $\begin{array}{l}\text { Mean } \\
\text { Square }\end{array}$ & F & Sig. \\
\hline Regression & 226.895 & 2 & 113.448 & 10.457 & $.000^{\mathrm{b}}$ \\
Residual & 683.468 & 63 & 10.849 & & \\
Total & 910.364 & 65 & & & \\
\hline
\end{tabular}

a. Dependent Variable: KeputusanPembelian

b. Predictors: (Constant), Promosi, KualitasProduk

(Sumber : Data primer diolah)

Pada tingkat signifikansi $\alpha=5 \%$, kualitas produk diketahui berpengaruh signifikan positif terhadap keputusan pembelian produk Indosat. Koefisien regresi sebesar $+0,575$ menunjukkan bahwa setiap peningkatan kualitas produk sebesar +1 poin maka keputusan pembelian produk hanya akan meningkat sebesar 0,575 poin. Dengan $\alpha=5 \%$, dan kaidah hipotesis nol $\left(\mathrm{H}_{\mathrm{o}}\right)$ jika nilai

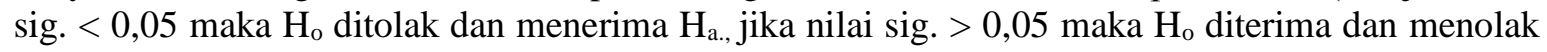
$\mathrm{H}_{\mathrm{a}}$, maka pada hipotesis berikut ini :

$\mathrm{H}_{\mathrm{o}}: \beta_{1} \neq 0$ - tidak terdapat pengaruh signifikan kualitas produk dan promosi terhadap keputusan pembelian. 
$\mathrm{H}_{\mathrm{a}}: \beta_{1}=0$ - terdapat pengaruh signifikan kualitas produk dan promosi terhadap keputusan pembelian.

Tabel 3. Koefisien Regresi

Coefficients $^{\mathrm{a}}$

\begin{tabular}{|c|c|c|c|c|c|c|}
\hline \multirow{2}{*}{\multicolumn{2}{|c|}{ Model }} & \multicolumn{2}{|c|}{$\begin{array}{l}\text { Unstandardized } \\
\text { Coefficients }\end{array}$} & $\begin{array}{l}\text { Standardized } \\
\text { Coefficients }\end{array}$ & \multirow[t]{2}{*}{$\mathrm{t}$} & \multirow[t]{2}{*}{ Sig. } \\
\hline & & B & Std. Error & Beta & & \\
\hline \multirow{3}{*}{1} & (Constant) & 12.602 & 3.526 & & 3.574 & .001 \\
\hline & KualitasProduk & .575 & 166 & .504 & 3.463 & .001 \\
\hline & Promosi & -.013 & .257 & -.007 & -.051 & .960 \\
\hline
\end{tabular}

a. Dependent Variable: KeputusanPembelian

(Sumber : Data primer diolah)

Berdasarkan data hasil uji-t yang menunjukkan nilai Sig. konstanta $=0,001$, kualitas produk $=0,001(<0,05)$ maka $H_{0}$ ditolak atau dengan kata lain variabel kualitas produk cukup signifikan mempengaruhi keputusan pembelian produk kartu seluler Indosat. Sedangkan nilai Sig. promosi 0,960 menunjukkan bahwa variabel promosi tidak cukup signifikan mempengaruhi keputusan pembelian produk Indosat.

Tabel 4. Koefisien Korelasi Correlations

\begin{tabular}{|c|c|c|c|c|}
\hline & & $\begin{array}{c}\text { KualitasProdu } \\
\text { k }\end{array}$ & $\begin{array}{l}\text { Promo } \\
\text { si }\end{array}$ & $\begin{array}{l}\text { Keputusan } \\
\text { Pembelian }\end{array}$ \\
\hline \multirow{4}{*}{ KualitasProduk } & Pearson & 1 & $661^{* *}$ & $499^{* * *}$ \\
\hline & Correlation & & & \\
\hline & Sig. (2-tailed) & & .000 & .000 \\
\hline & $\mathrm{N}$ & 66 & 66 & 66 \\
\hline \multirow{3}{*}{ Promosi } & Pearson & $.661^{* *}$ & 1 & $.326^{* *}$ \\
\hline & Sig. (2-tailed) & .000 & & .008 \\
\hline & $\mathrm{N}$ & 66 & 66 & 66 \\
\hline \multirow{3}{*}{ KeputusanPembelian } & Pearson & $.499^{* *}$ & $.326^{* *}$ & \\
\hline & Sig. (2-tailed) & .000 & .008 & \\
\hline & $\mathrm{N}$ & 66 & 66 & \\
\hline
\end{tabular}

**. Correlation is significant at the 0.01 level (2-tailed).

(Sumber : Data primer diolah, 2014)

Nilai koefisien korelasi menunjukkan bahwa hubungan atau korelasional untuk variabel kualitas produk dengan keputusan pembelian adalah $+0,499$ dan sig $=0,000$ dan promosi ke keputusan pembelian adalah $+0,326$ dan sig $=0,008$. Dapat disimpulkan bahwa antara kualitas produk, promosi dan keputusan pembelian terdapat korelasi positif yang kurang kuat (besaran korelasi 0,4999 dan 0,326 < 0,5. Namun demikian karena besaran korelasi bersifat positif (+) maka hal ini menunjukkan bahwa semakin tinggi kualitas produk dan promosi Indosat, keputusan untuk membeli produk Indosat tetap ada kecenderungan meningkat.

Secara keseluruhan, hasil penelitian menunjukkan bahwa pengaruh kualitas produk terhadap keputusan pembelian kartu seluler Indosat pada mahasiswa Politeknik Sawunggalih Aji Purworejo cukup signifikan. Walaupun korelasi positif keduanya kurang kuat, hal ini tetap perlu mendapat perhatian lebih dari PT Indosat, tbk. Disamping berbagai faktor dominan yang mempengaruhi keputusan pembelian produk Indosat, kualitas produk tetap menjadi acuan pembelian. Oleh karena itu Indosat dapat lebih memberikan berbagai fasilitas pada produknya. 
Jika memperhatikan data bahwa mayoritas mahasiswa menggunakan kartu M3, dapat disimpulkan bahwa untuk kalangan muda produk kartu M3 menjadi favorit pilihan. Kondisi tersebut sangat sesuai dengan target sasaran M3 yang memang diprioritaskan untuk kalangan muda. Indosat dapat lebih meningkatkan kualitas kartu M3 dengan dukungan program yang lebih menyasar kalangan muda, khususnya pelajar dan mahasiswa. Hal ini mengingat bahwa tingkat pembelian pulsa kalangan muda mayoritas di bawah 50.000,- perbulan.

Hasil penelitian juga menunjukkan bahwa kartu Mentari kurang diminati oleh kalangan muda. Walaupun Indosat memprioritaskan kartu M3 untuk membidik kalangan muda, tingkat penerimaan kartu Mentari di kalangan muda juga perlu ditingkatkan dengan program dan fasilitas yang sesuai bagi kalangan muda seperti masa aktif yang lebih panjang, biaya SMS lebih murah, program komunitas dan lainnya. Selain itu promosi iklan tidak terlalu berpengaruh pada keputusan pembelian produk Indosat. Indosat dapat lebih mempriorotaskan program promosinya pada komponen yang selektif seperto dengan kegiatan life event, sponsorship, program kepedulian sosial dan sebagainya.

Di luar kualitas produk dan promosi, ada faktor-faktor yang lebih dominan mempengaruhi keputusan pembelian produk kartu seluler Indosat. Sebagai contoh, berdasarkan wawancara kepada responden, mereka memilih menggunakan kartu dari Indosar karena biaya yang murah terutama untuk SMS dan teman-temannya banyak yang menggunakan kartu Indosat. Disamping itu faktor sudah lama menggunakan kartu Indosat dan nomer kartu selulernya sudah diketahui banyak pihak sehingga kalau berganti kartu justru akan mengganggu komunikasi. Dari kondisi itu maka Indosat dapat meningkatkan programnya dengan memanfaatkan aspek pertemanan para pelanggannya, pemberian reward yang lebih realistis untuk pelanggan lama dan lainnya dibanding meningkatkan program promosi yang tidak langsung bersentuhan dengan para pelanggan, khususnya untuk kalangan muda.

Hasil penelitian ini sejalan dengan beberapa penelitian lain sebelumnya. Dalam penelitian Dipura (2013:155), diektahui bahwa secara bersama-sama variabel citra merek dan persepsi kualitas berpengaruh positif dan signifikan terhadap loyalitas merek. Hal ini berarti semakin kuat citra merek dan persepsi kualitas maka loyalitas merek pengguna kartu Indosat semakin tinggi, sebaliknya semakin lemah citra merek dan persepsi kualitas maka loyalitas merek pengguna karti Indosat semakin rendah. Fauzul Adzim (2014 : 47) dalam penelitiannya yang menggunakan analisis regresi logistik menunjukkan bahwa variabel produk, harga, promosi, saluran distribusi, dan proses berpengaruh signifikan terhadap keputusan brand switching pada kartu seluler. Variabel proses berpengaruh dominan terhadap keputusan brand switching pada kartu seluler. Sedangkan pada hasil penelitian Widodo (2014: 12) diperoleh bahwa produk dan distribusi berpengaruh terhadap intensi pembelian dan secara bersamaan produk, harga, distribusi dan promosi berpengaruh terhadap intensi pembelian. Kualitas produk memiliki pengaruh positif terhadap keputusan pembelian konsumen kartu Indosat, baik secara parsial maupun secara simultan. Variabel kinerja produk merupakan faktor paling dominan dalam mempengaruhi keputusan pembelian tersebut. (Suprajang, $2013: 7$ ).

Di balik citra positif suatu produk, karakteristik, atribut-atribut dan kualitas produk tentu tetap menjadi aspek yang tidak dapat dikesampingkan. Para konsumen akan menilai dan membandingkan kualitas produk dengan informasi yang diperolehnya mengenai produk tersebut dengan berbagai isyarat informasi yang dapat bersifat intrinsik maupun ekstrinsik (Schiffman dan Kanuk, 2008:162). Oleh karena itu berdasarkan hasil penelitian sebelumnya tersebut dan yang dilakukan, dapat disimpulkan bahwa kualitas produk dan promosi secara positif berpengaruh signifikan terhadap keputusan pembelian kartu Indosat. Dalam hal ini promosi produk Indosat yang selalu mengandung unsur 'komunikasi' juga harus memperhatikan aspek-aspek efektifitas. Beberapa Indikator komunikasi efektif dalam kegiatan promosi yang perlu diperhatikan yaitu (Eman Suherman, 2010:206) :

1. Waktu relatif singkat dan hasil komunikasi relatif banyak.

2. Pesan yang disampaikan dapat diterima dengan cermat.

3. Proses maupun hasil komunikasi dapat menyenangkan semua pihak.

4. Komunikasi yang dilakukan dapat mempengaruhi sikap khalayak.

5. Terjadi hubungan yang membaik antar unsur yang terlibat komunikasi.

6. Terbentuknya pola tindakan ideal dari pihak-pihak yang berkomunikasi. 


\section{KESIMPULAN}

Berdasarkan penelitian yang telah dilakukan pada mahasiswa pengguna produk kartu seluler Indosat, dapat disimpulkan bahwa variabel kualitas produk cukup signifikan positif mempengaruhi keputusan pembelian, sedangkan variabel promosi tidak cukup signifikan mempengaruhi keputusan pembelian produk Indosat. Namun antara kualitas produk, promosi dan keputusan pembelian terdapat korelasi positif yang kurang kuat.

Berdasarkan hasil uji determinasi, variabilitas variabel dependen (keputusan pembelian) yang dapat dijelaskan oleh variabilitas variabel independen (kualitas produk dan promosi) hanya sebesar 24,9\%. Berarti masih banyak aspek dominan yang mempengaruhi keputusan pembelian kartu seluler Indosat. Dengan nilai F $=10,457(0,000<0,05)$, secara bersama-sama variabel kualitas produk dan promosi mempengaruhi keputusan pembelian kartu seluler Indosat.

Pada tingkat signifikansi $\alpha=5 \%$, kualitas produk berpengaruh signifikan positif terhadap keputusan pembelian. Berdasarkan hasil uji-t, nilai Sig. konstanta $=0,001$, kualitas produk $=0,001$ $(<0,05)$ maka $\mathrm{H}_{\mathrm{o}}$ ditolak (variabel kualitas produk cukup signifikan mempengaruhi keputusan pembelian). Dengan nilai Sig. promosi 0,960, variabel promosi tidak cukup signifikan mempengaruhi keputusan pembelian produk Indosat. Antara kualitas produk, promosi dan keputusan pembelian terdapat korelasi positif yang kurang kuat (besaran korelasi $+0,4999$ dan $+0,326<0,5)$. Namun semakin tinggi kualitas produk dan promosi Indosat, keputusan untuk membeli produk Indosat tetap ada kecenderungan meningkat.

Mencermati hasil analisis yang dilakukan, ada beberapa saran atau rekomendasi yang dapat disampaikan yaitu sebagai berikut :

1. Di samping faktor dominan yang mempengaruhi keputusan pembelian, Indosat dapat lebih memberikan berbagai fasilitas pada kartu seluler produknya.

2. Indosat dapat lebih meningkatkan kualitas kartu M3 dengan berbagai dukungan program untuk kalangan muda. Hal ini mengingat bahwa tingkat pembelian pulsa kalangan muda mayorita di bawah 50.000,- perbulan. Sehingga dimungkinkan Indosat dapat lebih meningkatkan penjualan kartu M3 dengan dukungan berbagai program dan fasilitas.

3. Pembelian kartu Mentari di kalangan muda dapat ditingkatkan dengan mengusung program dan fasilitas yang mampu diterima oleh mereka seperti masa aktif / tenggang yang lebih lama dan biaya SMS yang lebih murah.

4. Indosat dapat lebih mempriorotaskan progam promosinya pada komponen selektif seperti kegiatan life event, sponsorship, kepedulian sosial dan lainnya.

5. Pemanfaatan aspek pertemanan antar para pelanggan, pemberian reward yang lebih realistis untuk pelanggan lama

6. dan lainnya perlu menjadi prioritas bagi Indosat dalam program pemasarannya dibanding meningkatkan program promosi yang tidak langsung bersentuhan secara langsung dengan para pelanggan, khususnya untuk kalangan muda.

\section{DAFTAR PUSTAKA}

Adzim, Fauzul. 2014. Pengaruh Produk, Harga, Promosi, Saluran Distribusi, dan Proses Terhadap Keputusan Brand Switching Pada Kartu Telepon Seluler. Jurnal Manajemen Bisnis. FEB UMM. Vol 4 no. $2: 39-48$.

Arman, Fauzi. 2010. Analisis Faktor-faktor yang Mempengaruhi Keputusan Pembelian Laptop Merek Acer pada Mahasiswa Fakultas Kesehatan Masyarakat USU. Medan : Universitas Sumatera Utara.

Budiarti, Tuti. 2012. Pengaruh Citra Merek (Brand Image) Terhadap Pengambilan Keputusan Pembelian Motor Kawasaki Pada PT Diana Indonesia di Makassar. Makassar : Universitas Hasanudin.

Dipura, Bayu Andika. 2013. Pengaruh Citra Merek Dan Persepsi Kualitas Terhadap Loyalitas Merek. Jurnal Manajemen Bisnis. FEB UMM. Vol 3 No.1 2013 : 145-157.

Djumaing, Dharmayansyah. 2012. Analisis Faktor-Faktor Yang Memengaruhi Konsumen Terhadap Pembelian Semen Pada PT. Semen Tonasa di Kabupaten Pangkep. Makassar : Universitas Hasanudin. 
Pitoyo, Arif. 2 Agustus 2013. Pengguna Capai 56,5 Juta, Pendapatan Indosat Naik 13,7 Persen. https://www.merdeka.com/teknologi/pengguna-capai-565-juta-pendapatan-indosat-naik-137persen.html. Diakses 14 November 2014.

Qarina. 2012. Analisis Faktor-Faktor Yang Mempengaruhi Permintaan Kredit Sepeda Motor di Kota Makassar. Makassar : Universitas Hasanudin.

Rouzni Noor, Achmad. 24/10/2012 08:45 WIB. Indosat Masih Ingin Gaet Jutaan Pelanggan BlackBerry. Jakarta : http://www.detik.com.

Schiffman, Leon dan Kanuk, Leslie Lazar. 2008. Perilaku Konsumen. Jakarta : PT Indeks

Suherman, Eman. 2010. Business Entreneur, Panduan Praktis Berwirausaha. Bandung : Alfabeta.

Suprajang, Sandi Eka. Juni 2013. Pengaruh Kualitas Produk terhadap pengambilan keputusan Pembelian Konsumen dalam membeli Produk. Jurnal Kompilasi Ilmu Ekonomi. STIE Kesuma Negara Blitar. Volume 5 No. 1 : 7-15.

Widodo, Adi Prasetyo. Oktober 2014. Perilaku Konsumen Dalam Membangun Intensi Pembelian Pada Produk Sepatu Converse Di Jakarta Barat. Jurnal Akuntansi Dan Manajemen Esa Unggul. Fakultas Ekonomi/Manajemen Universitas Esa Unggul. Vol. 2, No. 2 : 2-17. . 14 Mei 2012. Triwulan Pertama 2012 Pelanggan Indosat 52,1 Juta. Jakarta : htt://www.republika.co.id.

. 14 Desember 2012. Indosat Anggarkan Belanja Modal Rp7,6 Triliun 2013. Jakarta : http://www.investor.co.id. 